\title{
A PARTICIPAÇÃO EVANGÉLICA NA POLÍTICA BRASILEIRA E SUA IDENTIFICAÇÃO COM GOVERNOS DE DIREITA
}

\section{Evangelical Participation in Brazilian Politics And its Identification With Right Governments}

\author{
Wander de Lara Proença ${ }^{1}$
}

\section{RESUMO}

As últimas eleições no Brasil têm evidenciado uma crescente participação de evangélicos no cenário político e uma identificação majoritária com governos de direita. Um marco representativo deste comportamento ocorreu no expressivo apoio dado à eleição presidencial de Bolsonaro e na ocupação de diversos cargos no exercício de seu governo. $\mathrm{O}$ artigo apresenta o percurso histórico do comportamento evangélico na esfera política e também os fatores que historicamente configuram o imaginário deste segmento religioso, orientando suas práticas de aproximação da direita. Prioriza-se como referência a noção conceitual de "imaginário", conforme seu emprego pela chamada nova história política. Como fontes de análise, além de textos bibliográficos, utilizam-se recursos audiovisuais, mídias sociais e letras de músicas do universo evangélico brasileiro.

Palavras-chave: Evangélicos; política de direita; Bolsonaro; imaginário.

\begin{abstract}
The last elections in Brazil have shown a growing participation of evangelicals in the political scenario and a majority identification with right-wing governments. A representative mark of this behavior occurred in the expressive support given to the presidential election of Bolsonaro and in the occupation of several positions in the exercise of his government. The article presents the historical trajectory of evangelical behavior in the political sphere and also the factors that historically configure the imagery of this religious segment, guiding its approaches to the right. Priority is given to the conceptual notion of "imaginary", as used by the so-called new political history. As sources of analysis, in addition to bibliographic texts, audiovisual resources, social media and lyrics from the Brazilian evangelical universe are used.
\end{abstract}

Key words: Evangelicals; right-wing politics; Bolsonaro; imaginary.

\section{Introdução}

A participação de evangélicos ${ }^{2}$ no cenário político brasileiro tem se mostrado crescente e cada vez mais decisiva nos processos eleitorais. Aumenta o número de candidatos que se

\footnotetext{
${ }^{1}$ Professor da Universidade Estadual de Londrina e da Faculdade Teológica Sul Americana / Londrina-PR. Membro do Laboratório de Estudos sobre as Religiões e Religiosidades/ UEL.

${ }^{2}$ Termo genericamente aqui empregado para identificar um segmento cristão não católico, que esconde, por vezes, a diversidade dessa tipologia de crença. Em linhas gerais, estes grupos egressos da reforma religiosa ocorrida no
} 
apresentam, por exemplo, nos horários de propaganda eleitoral, utilizando os títulos religiosos de pastor, missionário, bispo, apóstolo, e assim por diante. Nas eleições para presidente da República, em 2018, o posicionamento evangélico foi determinante para os resultados obtidos naquele pleito. $\mathrm{O}$ segundo turno foi polarizado por um candidato que trazia como parte de seu slogan de campanha a frase carregada de simbolismo, "Deus acima de todos", prometendo defender a fé, a família, o controle na educação dos filhos, o combate à chamada ideologia de gênero nas escolas, além de oposição às relações homoafetivas, e, no outro extremo, um concorrente que reeditava no imaginário ${ }^{3}$ cristão a fantasmagoria do comunismo ateísta, representando ameaça aos valores da família chamada tradicional, acusado inclusive de ser o autor, quando fora ministro da educação, do chamado de "kit gay", sob suspeição de que iria erotizar prematura e indevidamente os estudantes. Tal cenário eleitoral levou pastores de influente liderança a cederem espaços nas liturgias religiosas sob seu comando, inclusive em grandes eventos, para divulgação do candidato que, não obstante se manter oficialmente católico, passou a ser identificado como representante da fé evangélica. Passada a eleição, pesquisas apontaram que 70\% dos evangélicos votaram em Jair Bolsonaro, representando cerca de 11 milhões de votos, número corresponde à diferença obtida na vitória sobre Fernando Haddad, concorrente petista (ALVES, 2018).

O texto deste artigo analisa duas questões centrais: como se construiu historicamente esse percurso de participação evangélica na política brasileira? Por que os evangélicos se identificam majoritariamente com governos de direita?

\section{Percursos da participação evangélica no cenário político brasileiro}

\footnotetext{
século XVI podem ser situados em duas grandes ramificações. Primeiro, o protestantismo, formado por luteranos, presbiterianos, batistas, anglicanos e metodistas, estabelecido no Brasil ao longo do século XIX. A segunda vertente, o pentecostalismo, inserida no Brasil a partir de 1910, procedente dos Estados Unidos, que se divide em três grandes tipologias: o pentecostalismo clássico, representado pelas igrejas Assembleias de Deus e Congregação Cristã no Brasil; o pentecostalismo neoclássico, surgido nos anos de 1950, tendo como representantes as igrejas do Evangelho Quadrangular, O Brasil Para Cristo e Deus é Amor; e, por fim, o neopentecostalismo, formado a partir dos anos 1970, tendo como principais expoentes a Igreja Universal do Reino de Deus, sob liderança de Edir Macedo, a Internacional da Graça de Deus, de R.R. Soares, Renascer em Cristo, liderada por Estevam Hernandes e Sônia Hernandes, e, mais recentemente, a Igreja Mundial do Poder de Deus, fundada por Valdemiro Santiago.

${ }^{3}$ O termo "imaginário" é aqui utilizado conforme seu emprego na chamada nova história política, que analisa as práticas de um dado sistema de poder ou o comportamento social guiados também por componentes simbólicos ligados a crenças e visões de mundo. Em sua obra Multidões em cena: propaganda política no varguismo e no peronismo, Maria Helena Capelato destaca o papel do imaginário e diversas estratégias para a construção da imagem pública de líderes carismáticos ou populistas, destacando para isso o uso que se faz de "imagens, símbolos, mitos, utopias" (CAPELATO, 2009, p.28).
} 
Até os anos de 1950, sob influência de uma escatologia projetada para o "celeste porvir", ${ }_{4}^{4}$ prevaleceu entre os evangélicos brasileiros a ideia de se manterem indiferentes às questões políticas do país. Comportando-se como outsiders, à margem, com estilo de vida determinado pela crença, apegavam-se ao lema: "o crente não se mete em política". 5

Uma primeira mudança nesse comportamento ocorreu a partir do golpe civil-militar de 1964. No contexto da Guerra Fria, igrejas evangélicas se aproximaram estrategicamente do regime militar como forma de proteção frente ao que consideravam uma ameaça do comunismo, visto como ateísta, e que - segundo diziam - poderia fechar as igrejas, perseguir os cristãos e interferir nos valores tradicionais da família. Desse modo, tais comunidades de fé funcionaram durante aquele regime como caixas de ressonância que reverberavam em suas pregações a ideologia norte-americana de combate ao que nominavam de "demônio soviético", ou "reino do anticristo". 6

Outra mudança, no sentido de uma mobilização política, ocorreu com a redemocratização do país. O evento inaugural foi a eleição de 1986 para o Congresso Nacional Constituinte, quando a igreja Assembleia de Deus abandonou sua tradicional posição apolítica e apresentou uma lista oficial de candidatos. (MARIANO; PIERUCCI, 1996). Surgia, aí, um novo slogan: “irmão vota em irmão". A participação político-partidária, instrumentalizada, buscava assegurar interesses e valores evangélicos na nova Carta Magna. Buscava-se fazer frente à difusão de ideias conspiratórias de que a Igreja Católica pretendia retomar a posição de

\footnotetext{
${ }^{4}$ Expressão empregada pelo pesquisador Antônio Gouvêa Mendonça, em sua obra $O$ celeste porvir: a inserção do protestantismo no Brasil, em que aponta a visão escapista da história que guiou os evangélicos a partir dos chamados avivamentos espirituais ocorridos nos Estados Unidos, no século XIX, elementos estes também difundidos em solo brasileiro a partir das missões protestantes e do pentecostalismo (MENDONÇA, 2008).

${ }^{5}$ Esse é o comportamento ainda adotado por algumas denominações evangélicas, como a Congregação Cristã no Brasil, fundada em 1910, considerada ao lado da Igreja Assembléia de Deus as matrizes do pentecostalismo brasileiro.

${ }^{6}$ Houve exceções, de líderes protestantes que se posicionaram contrários à ditadura daquele regime, engajados em movimentos evangélicos progressistas, como a Teologia da Libertação - corrente teológica surgida na década de 1960, liderada pelo sacerdote peruano Gustavo Gutierrez, e que teve como um de seus principais expoentes o teólogo brasileiro Leonardo Boff e, do lado protestante, Rubem Alves, escritor e professor à época do Seminário Presbiteriano de Campinas - que militavam em causas sociais, a exemplo da luta pela terra ou defesa de minorias expostas à violência do governo ditatorial. Em razão disto, foram combatidos, tanto pelos mecanismos de repressão do próprio regime, como pelas próprias igrejas de que faziam parte, perseguidos e expulsos como hereges. Magali Cunha, que integrou a Comissão da Verdade, comenta que 22 evangélicos foram presos pelo regime, sofrendo tortura; 7 são tidos como mortos ou desaparecidos; 14 foram exilados, com destaque para metodistas e presbiterianos. (CUNHA, 2021). Este cenário ocasionou o que à época ficou conhecido como "inquisição sem fogueiras" - título de um livro do teólogo João Dias de Araújo, publicado em 1976, que descreve as diversas formas de repressão sofridas por pastores ligados ao protestantismo, em razão das críticas que faziam ao apoio dado pela igreja ao regime militar ditatorial no Brasil (ARAÚJO, 1976).
} 
religião oficial do Estado e com isso cercear a liberdade religiosa dos evangélicos. Também fortalecer seu combate aos demais grupos concorrentes, como umbandistas e católicos, assim como aos que ofereciam alguma ameaça aos seus valores, como homossexuais, feministas, esquerdistas, assim genericamente identificados. O resultado foi a eleição de 32 deputados evangélicos para a Câmara Federal. Nascia a primeira bancada evangélica, encabeçada sobretudo por pentecostais pertencentes à igreja Assembléia de Deus.

Um fenômeno novo até então se instalava; igrejas lançaram membros e/ou clericato para assumir funções legislativas e lutar por suas bandeiras. Estes novos políticos oriundos de comunidades religiosas evangélicas podem ser caracterizados, conforme a boa categorização de Freston (1993), em candidatos oficiais: são escolhidos, lançados à campanha e eleitos pelas igrejas a que pertencem. Sua vida política era do começo ao fim obra da instituição religiosa. (SILVA, 2017, p.14).

Esse primeiro quadro parlamentar, ocupando o chamado centrão, notabilizou-se pelo conservadorismo moral e fisiologismo. Nas eleições de 1989, no segundo turno, encabeçaram o explícito apoio evangélico ao candidato Fernando Collor, por considerarem o candidato Lula, do Partido dos Trabalhadores, uma ameaça à liberdade religiosa, que poderia estabelecer o comunismo, perseguir os evangélicos, fechar igrejas, enfim, mexer com valores da fé cristã. Membros da bancada evangélica também negociaram votos em troca de interesses dos grupos que representavam, como por exemplo, na extensão do mandato do governo de José Sarney para cinco anos, tendo recebido em contrapartida recursos públicos a fundo perdido, além concessão de canais de emissoras de rádio para as igrejas de que faziam parte. ${ }^{7}$ A partir daí, ganhou visibilidade o ativismo político de pastores como cabos eleitorais e comunidades religiosas que funcionam como partidos em períodos de eleição; os evangélicos criaram frentes parlamentares, passaram a ocupar cargos de secretários e de ministros de estado: "Esse fenômeno se espalhou Brasil afora nos anos seguintes. Nas casas legislativas estaduais e municipais políticos evangélicos foram assumindo cadeiras e desde então fazem parte da vida política brasileira de maneira significativa (SILVA, 2017, p.15). Vale destacar o caso da Igreja Universal do Reino de Deus (IURD) no campo político, quando no início da década de 1990 fundou seu próprio partido, o Partido Republicano Brasileiro (PRB), definindo eleger um

\footnotetext{
${ }^{7}$ A bancada evangélica, fragmentada em dezenas de denominações e partidos políticos, assegura forte poder de barganha ou moeda de troca o jogo político, sobretudo pela posição ocupada no centrão, que favorece o fisiologismo, atendendo a interesses dos grupos religiosos que representam. Em 2020, por exemplo, quando houve uma polêmica sobre o pagamento de impostos pelas igrejas evangélicas, Bolsonaro interveio, pressionando a Receita Federal a perdoar dívidas de impostos das igrejas. O assunto foi tema de uma reunião entre ele, o secretário do fisco, José Tostes, e o deputado David Soares (DEM-SP), filho do missionário R.R. Soares. (UOL, 2021).
} REVISTA RELEGENS THRÉSKEIA - 2021 - UFPR 
deputado federal e um estadual para cada unidade da federação, além de vereadores, com base numa calculada distribuição geográfica dos candidatos:

A cúpula da igreja, formada por um conselho de bispos da confiança de Edir Macedo, indica candidatos em um procedimento absolutamente verticalizado, sem a participação da comunidade. Os critérios para a escolha desses candidatos geralmente têm base em um certo recenseamento que se faz sobre o número de eleitores em cada igreja ou em cada distrito. Assim, cada região tem apenas dois candidatos, que seriam o candidato federal e o estadual. (SURUAGY, 2017, p.2).

Mais recentemente, os parlamentares da Bancada Evangélica apoiaram o Movimento Brasil Livre, votaram maciçamente no impeachment de Dilma Rousseff, engajaram-se favoravelmente no governo Temer, muitos abraçaram teorias conspiratórias do escritor Olavo de Carvalho, alguns passaram a reproduzir o discurso negacionista, em relação, por exemplo, à ditadura militar e seus abusos, sob o argumento de que ela teria protegido o país da ameaça comunista e defendido valores da família chamada de tradicional. Ao apoiarem em 2018 a eleição de Bolsonaro, os evangélicos visualizavam neste personagem a concretização de um anseio de ter um candidato que pudesse responder às suas pautas mais conservadoras:

Os evangélicos nunca conseguiram se unir para eleger um dos seus candidatos à presidência da República. Esse sonho não se concretizou com Marina Silva (pentecostal) ou Antony Garotinho (presbiteriano). Porém, a vitória de Bolsonaro lhes trouxe a percepção de que "um homem de Deus" assumiu a presidência, e que uma Frente Parlamentar Evangélica, com cerca de 200 deputados (40\% deles), está lá na Câmara Federal para lhe dar sustentação (Estado de S.Paulo, 15/9/19). (CAMPOS, 2019, p.366).

Bolsonaro soube pavimentar uma via de aproximação deste público. No Congresso, onde atuou como deputado por sete mandatos, os parlamentares mais próximos a ele pertenciam à bancada evangélica. Engajou-se nas posições conservadoras dessa bancada; juntou-se ao ativismo corporativista em prol de forças armadas e policiais e também numa cruzada moral contra reivindicações de direitos de feministas e militantes nas questões de gênero:

Bolsonaro começou a ficar conhecido no meio evangélico depois de ter levado uma cusparada do deputado Jean Wyllys (PSOL-RJ) e, no Congresso, ter passado a pregar contra o casamento entre gays. Para o evangélico, o que é prioritário é a pauta conservadora, o combate ao aborto, à união LGBT e à própria esquerda, dada a leitura que fazem do socialismo e do comunismo. (VELOSO, 2018, p.2). 
Mais um passo decisivo foi dado quando liderou a oposição política à distribuição do Caderno Escola sem Homofobia, ${ }^{8}$ pelo Ministério da Educação sob o comando de Fernando Haddad, a alunos dos ensinos fundamental e médio:

Composto por um caderno com instruções ao professor, boletins informativos e cinco vídeos, o material visava combater a "discriminação por orientação sexual". O capitão e parlamentares evangélicos o rotularam, pejorativamente, de "kit gay", acusaram-no de fazer apologia à homossexualidade e à promiscuidade e de ser uma artimanha petista para perverter a sexualidade das crianças e destruir as famílias. (GERARDI; MARIANO, 2019, p.334,335).

Posteriormente, em 2017, em entrevista à Folha Uol, reconheceu: "o kit gay foi uma catapulta na minha carreira política" (apud GERARDI; MARIANO, 2019, p.335). Comentando esse aspecto, Cunha (2019, p.1) observa que "Bolsonaro foi muito bem instruído no discurso que alimentou a pauta de costumes de sua campanha, afetando fortemente o imaginário evangélico conservador calcado na proteção da família tradicional, na heteronormatividade e no controle dos corpos das mulheres". Já candidato, seu discurso avançou em bandeiras moralistas, alternando com frequência referências ao Hino Nacional e repetição à exaustão dos dizeres bíblicos: "conhecereis a verdade e a verdade vos libertará". Esta frase, a despeito de sua interpretação anacrônica e fora de contexto, juntou-se ao slogan "Brasil acima de tudo e Deus acima de todos", reverberando favoravelmente no imaginário evangélico (CAMPOS, 2019, p.365). Em 11 de maio de 2016, um dia antes do Senado decidir afastar Dilma Rousseff da Presidência, Bolsonaro e seus três filhos ${ }^{9}$ viajaram a Israel na companhia do pastor Everaldo, da Igreja Assembleia de Deus e presidente do Partido Social Cristão - PSC. Lá, a família Bolsonaro foi batizada pelo referido pastor no Rio Jordão, local sagrado pela tradição cristã que afirma ter Jesus ali também recebido seu batismo. ${ }^{10}$ Esse ato simbolizou duas coisas: a filiação de Bolsonaro ao PSC e "a aliança com as Assembleias de Deus, apesar de formalmente continuar católico" (CUNHA, 2019, p.3). Vídeos com essas imagens foram imediatamente publicados em todas as mídias sociais do parlamentar.

\footnotetext{
${ }^{8}$ André Gerardi e Ricardo Mariano observam que: "Sob pressão da bancada evangélica, que ameaçou obstruir votações no plenário da Câmara e convocar Antônio Palocci, então ministro da Casa Civil, para explicar a evolução de seu patrimônio, a presidente Dilma Roussef vetou a distribuição do material didático". (GIRARDI; MARIANO, 2019, p.335).

${ }^{9}$ Também políticos: Flávio, Carlos e Eduardo Bolsonaro.

${ }^{10}$ As referências sempre positivas que Bolsonaro estabelece em relação a Israel têm uma ressonância bastante valorativa no imaginário evangélico, que em sua escatologia considera aquela nação divinamente escolhida para uma missão salvacionista. Ainda em 2019, a bancada evangélica do Congresso Nacional pressionou fortemente o governo federal pela mudança da Embaixada do Brasil em Israel de Tel Aviv para Jerusalém, seguindo o encaminhamento feito pelos Estados Unidos da América.
}

REVISTA RELEGENS THRÉSKEIA - 2021 - UFPR 
A partir do segundo semestre daquele ano, os templos evangélicos se transformaram em bastiões do antipetismo. ${ }^{11}$ Com habilidade, os pastores costumam indicar candidatos de forma discreta, já que tal prática é contra a lei: "Eles falam dos candidatos durante o culto de maneira sutil ou levam candidatos para serem apresentados e orar com os fiéis", ou então, outra tática costumeiramente utilizada "é recrutar fiéis que distribuem panfletos perto dos templos" (VELOSO, 2018, p.5). Assim, Bolsonaro passou a ter apoio de lideranças evangélicas de grande influência sobre seus fiéis e com expressiva presença na mídia; alguns desses, inclusive, proprietários de redes de televisão. Pastores usaram as redes sociais para demonizar os governos petistas, o PT e seus candidatos, alertando contra Fernando Haddad, um representante da "esquerda" e do "comunismo". 12

Um dos primeiros líderes a apoiá-lo foi Silas Malafaia - filho de um ex-combatente da Marinha - líder da Assembleia de Deus Vitória em Cristo, que tem programas na TV, uma legião de seguidores nas mídias sociais e costuma aparecer com frequência no Facebook e no Instagram de Jair Bolsonaro. Amigo do presidente já por uma década, conheceu o então deputado durante um culto em sua igreja, da qual sua terceira mulher, Michele Firmo, era membro à época. Em março de 2013, Malafaia os casou numa cerimônia no Rio de Janeiro. Durante a campanha, ele se orgulhava de apoiar o candidato do PSL à Presidência: "Não tem nenhum líder religioso que faça mais vídeos apoiando Bolsonaro do que eu" (LEIA JÁ, 2018, p.2). Também José Wellington Bezerra, pastor presidente da Igreja Assembleia de Deus, a maior congregação evangélica do país, com mais de 13 milhões de adeptos, durante um culto em que celebrava seu aniversário de 84 anos, anunciou no púlpito: “De todos os candidatos, o único que fala o idioma do evangélico é Bolsonaro. Não podemos deixar a esquerda voltar ao poder" (ÉPOCA, 2018, p.2). Além destes, foi bastante decisivo o apoio de Edir Macedo, que anunciou no Facebook e em outras mídias sua predileção por Bolsonaro, conclamando os fiéis iurdianos a votar neste candidato: “A sua candidatura decolou rapidamente após o atentado de 6/9/18. O seu sofrimento, as cirurgias e a preservação da morte foram considerados 'intervenção

\footnotetext{
${ }^{11}$ Isabel Veloso observa que, "Apesar de o PT não ser um partido que tenha uma agenda comunista ou socialista, os evangélicos imaginam que a esquerda é comunismo, e comunismo é algo ateu, contrário à família. Essa é a visão preponderante. É uma visão simples de associar um selo. Esquerda, então comunista. Comunista, então ateia. Ateia, contra a família e pró-união homoafetiva e aborto, por exemplo" (VELOSO, 2018, p.6).

${ }^{12}$ Sobre a influência ou peso do apoio dos principais líderes evangélicos brasileiros em favor de Bolsonaro, pesquisas indicam que os evangélicos são os religiosos brasileiros que mais comparecem a cultos e os que mais contribuem financeiramente com suas igrejas. Segundo o Estudo Eleitoral Brasileiro (ESEB), os evangélicos aparecem com $83 \%$ de frequência aos cultos, ante $36 \%$ dos católicos e $49 \%$ dos espíritas (ESEB, 2018). "É o local onde adquirem muita informação. Vão mais ao culto, interagem mais e estão mais abertos a falar de política do que na Igreja Católica, por exemplo. A rede deles é mais forte" (VELOSO, 2018, p.5).
}

REVISTA RELEGENS THRÉSKEIA - 2021 - UFPR 
divina'. Os evangélicos oraram intensamente pela recuperação de seu candidato" (CAMPOS, 2019, p.362).

Eleito presidente, manteve a estratégica gestualidade simbólica, comparecendo a diversos eventos evangélicos. $\mathrm{O}$ deputado federal assembleiano, Marco Feliciano (Podemos/SP), tornou-se vice-líder de seu governo no Congresso e um dos principais interlocutores do presidente com a imprensa. Com sua assessoria, Bolsonaro passou a frequentar mais constantemente cultos evangélicos:

No domingo posterior à vitória, Bolsonaro foi ao culto da Igreja Assembleia de Deus Vitória em Cristo, agradecer o apoio recebido do pastor Malafaia. No decorrer da fala do pastor e o discurso do presidente eleito, os fiéis gritavam "mito, mito, mito" entrecortados por brados de "aleluia" e "glória a Deus". Malafaia, para mostrar intimidade com o presidente eleito, tratava-o como "este cara" ou "você", e ressaltou diversas vezes a "ação divina" na eleição de 28/10/18. (CAMPOS, 2019, p.361).

A representatividade dos gestos também acenou positivamente aos evangélicos quando, logo após o presidente tomar posse, sua esposa Michele Bolsonaro fez a retirada das imagens de santos católicos que ocupavam o altar em uma capela, situada ao lado do Palácio da Alvorada, para atividades religiosas dos que residem na moradia oficial da presidência. Um comportamento iconoclasta que repercute simbolicamente por representar a conquista de uma territorialidade até então identificada com o catolicismo (RÁDIO JOVEM PAN, 2020).

Em 2019, pela primeira vez um presidente participou da Marcha para Jesus, evento evangélico que ocorre anualmente em São Paulo, que reuniu nesta edição cerca de 3 milhões participantes. No palco, ladeado por expressivas lideranças evangélicas do país, ${ }^{13}$ vestindo a camiseta oficial daquela celebração, ao fazer uso da palavra foi ovacionado pela multidão aos gritos de "mito". Em seu pronunciamento, afirmou: "O Estado brasileiro é laico, mas o seu presidente é cristão. Vocês foram decisivos para mudar os destinos desta pátria maravilhosa chamada Brasil. No meu governo a família tradicional é respeitada”. Em seguida, a bispa Sônia Hernandes repetiu o slogan da campanha, "Brasil acima de tudo, Deus acima de todos". Bolsonaro encerrou sua participação defendendo o projeto que flexibiliza o uso de armas no país e simulando com o gesto das mãos o manejo de uma arma de fogo, enquanto recebia efusivos aplausos da multidão; ${ }^{14} \operatorname{logo}$ após, levantou juntamente com os pastores a bandeira de

\footnotetext{
${ }^{13}$ Como Estevam Hernandes, Sonia Hernandes, Valdemiro Santiago e Marco Feliciano.

${ }^{14}$ Ainda que de forma pouco expressiva, vale observar que se ouviram vaias ao presidente quando se dirigia ao público.
} 
Israel (RÁDIO JOVEM PAN, 2020). Neste mesmo ano compareceu ao Templo de Salomão, da Igreja Universal do Reino de Deus, na cidade de São Paulo, onde recebeu uma oração de consagração de Edir Macedo. Na ocasião, o bispo “declarou aos presentes que, no passado, ele convidou para ir à igreja um outro candidato presidencial, que acabou virando presidente, mas que não foi possível fazer com 'aquele determinado candidato' o mesmo que estava acontecendo naquele dia" (CUNHA, 2019, p.6). ${ }^{15}$ O jornal Folha de S.Paulo registrou que, "no altar, de joelhos e de costas para os fiéis, Bolsonaro foi ungido com óleo sobre a cabeça", recebendo de Macedo as seguintes palavras: "que Deus lhe dê sabedoria e coragem". (FOLHA de S.Paulo, 2019). Por esse gesto, além de uma articulação que assegura o apoio deste segmento, o presidente busca o fortalecimento de uma imagem religiosa atrelada ao governo. O presidente com frequência também participa de cultos da Igreja Batista Atitude, na Barra da Tijuca, na cidade do Rio de Janeiro, da qual a primeira-dama é membro. (O GLOBO, 2019). O líder daquela igreja, que em condições normais tem uma frequência média de oito mil pessoas aos domingos, é considerado uma espécie de "guru religioso da família Bolsonaro" (VEJA Rio, 2020, p.1). ${ }^{16}$

Em síntese, Bolsonaro pode ser considerado um "quase evangélico" (CAMPOS, 2019, p.367), ou "talvez seja o primeiro presidente do Brasil pós-católico" (COWEN, 2019), mas certamente, o presidente "mais próximo da imagem que os evangélicos mantêm deles próprios, de suas esperanças e do ideal de felicidade terrena" (CAMPOS, 2019, p.368). Declara-se católico, mas a esposa e um dos filhos são batistas; estes vínculos, somados a outros atos simbólicos fizeram dele "um candidato híbrido ideal, talvez o primeiro presidente pan-cristão, reunindo as vantagens eleitorais da identidade evangélica, mas evitando as desvantagens" (FRESTON, 2019, p.372).

\section{A identificação evangélica com a política de direita}

\footnotetext{
${ }^{15}$ Uma possível referência ao ex-presidente Luiz Inácio Lula da Silva (PT). Esta declaração demarca a diferença na relação dos governos petistas com a IURD: uma relação de cariz político, não religiosa, ao contrário de como denota ocorrer no caso de Bolsonaro.

16 Conforme reportagem da revista Veja Rio, "Durante o primeiro ano de governo, em todas as grandes comemorações ou nos momentos de aperto, o presidente Jair Bolsonaro e a primeira-dama Michelle contaram com um reforço, digamos, de instâncias superiores. [...]. Josué Valandro Jr., 50 anos, pastor da Igreja Batista Atitude, na Barra da Tijuca, é uma espécie de guru do casal. Com acesso direto à senhora Bolsonaro (falam-se pelo menos uma vez por semana por telefone ou mensagens no WhatsApp), em várias ocasiões, teve mais contato com o clã do que ministros e políticos do alto escalão”. (VEJA Rio, 2020, p.1).
} 
Ainda que de forma introdutória, é importante pontuar o que se define conceitualmente como direita. Três exemplos podem dimensionar politicamente esse termo. Primeiro, uma extrema-direita vinculada ao nazi-fascismo, emergente no intercurso temporal das duas Grandes Guerras. ${ }^{17}$ Umberto Eco, em seu texto $O$ fascismo eterno, ${ }^{18}$ comenta sobre essa referência inaugural: "Pode-se dizer que o fascismo italiano foi a primeira ditadura de direita que dominou um país europeu, e que, em seguida, todos os movimentos análogos encontraram uma espécie de arquétipo comum no regime de Mussolini” (ECO, 2019, p.28,29). Não obstante a diversidade e os elementos internos contraditórios do fascismo, o autor esboça uma lista de características que lhe são comuns, observando que "é suficiente que uma delas esteja presente para que o fascismo se aglomere ao seu redor": o culto da tradição; florescimento em contextos de frustrações individuais ou sociais; a ideia de uma ameaça externa (sendo isto fundamental para reforçar a identidade nacional); um ideário apocalíptico (no qual os inimigos podem e devem ser derrotados pelo movimento que, enfim, assumirá o controle, estabelecendo a paz e a ordem); desvalorização da vida de outrem ou sua banalização; enfraquecimento ou ataque a formas de conhecimento crítico (daí porque todos os livros escolares nazistas ou fascistas terem feito uso de um vocabulário empobrecido e de uma sintaxe elementar, de forma a limitar as ferramentas para o raciocínio complexo e a criticidade) (ECO, 2019, p.44-53).

Como segunda referência de direita pode ser apontado o contexto pós Segunda Guerra, quando os Estados Unidos protagonizaram contra o bloco soviético uma disputa de poder político, econômico e armamentista, na chamada Guerra Fria. No ambiente latino-americano, essas tensões ecoaram como voz convocatória norte-americana para enfrentamento do comunismo e da esquerda soviética, vistos, dentre outros aspectos, como representantes do ateísmo, da interferência do Estado nos valores morais e da família, além de tolhimento da liberdade. O combate a esta "esquerda ameaçadora" legitimou a insurreição de golpes contra a democracia com imposição de ditaduras na América, como foi o caso do governo civil-militar instaurado no Brasil em 1964. Dessa forma, fixava-se ainda mais no imaginário coletivo a identificação imediata de governos autoritários de direita como os defensores da pátria, da religião e da família.

\footnotetext{
17 Não deixando de considerar, obviamente, a existência de outros movimentos com perfis similares aos de comando de Benito Mussolini, na Itália, e Adolf Hitler, na Alemanha, como são os casos do "fascismo espanhol", liderado por Francisco Franco, e o "fascismo português", sob liderança de António de Oliveira Salazar.

${ }^{18}$ Produzido originalmente para uma conferência proferida na Universidade Columbia, em abril de 1995. REVISTA RELEGENS THRÉSKEIA - 2021 - UFPR
} 
Uma terceira demarcação emerge no contexto mais recente, como uma "nova direita", ou, em seus traços mais radicais, como um neofascismo. Umberto Eco observa que aquele arquétipo do nazi-fascismo - originário na Itália e Alemanha - não pode ser historicamente reeditado: "Se pensarmos sobre os governos totalitários que governaram a Europa antes da Segunda Guerra Mundial nós podemos facilmente dizer que seria difícil para eles reaparecerem sob a mesma forma em diferentes circunstâncias históricas" (ECO, 2019, p.22). Entretanto, relembra que é preciso considerar que práticas com perfis semelhantes têm permanentes reaparições no devir histórico. Dentre as características do "fascismo eterno", destacam-se, por exemplo, o medo do diferente, o machismo, a repressão e o controle da sexualidade, a exaltação de um líder, a propagação de um constante estado de ameaça, além do irracionalismo e oposição à análise crítica, expressos no discurso dos seus primeiros líderes: "as universidades são um ninho de comunistas" (ECO, 2019, p.49). Assim, longe de ser apenas um momento histórico ocorrido na Itália, a atual "ascensão mundial do flerte com o fascismo revela que este permanece como uma ameaça constante da nossa sociedade" (ECO, 2019, p.54-55). Francisco Carlos Teixeira (2018) comenta que "o fascismo faz parte da história brasileira", pontuando que "o fascismo brasileiro é o integralismo". ${ }^{19}$ Ancorado no lema "Deus, pátria e família", esse movimento político

surgiu oficialmente no ano de 1932, a partir da fundação da Ação Integralista Brasileira (AIB), que também foi, certamente, a maior organização integralista já existente. Inspirados por movimentos fascistas europeus, mas também por algumas organizações e grupos nacionais, sobretudo aqueles ligados a setores do conservadorismo e tradicionalismo católico, a AIB foi a principal organização fascista existente na história brasileira. (NETO, 2012, p.149).

Sobre o integralismo brasileiro, Odilon Neto destaca que anseios deste movimento estão novamente em moda, reinventando práticas fascistas, como substratos do pensamento de direita ou extrema-direita: “Os grupos neointegralistas, isto é, organizações integralistas surgidas após a morte do líder Plínio Salgado, buscam, desde a década de 1970, a inserção no âmbito político nacional, sobretudo como referência à extrema-direita e direita radical nacional” (NETO, 2012, p.147). Com o fim da ditadura civil-militar, a redemocratização e a promulgação da nova Constituição Federal, em 1988, instituíram-se o sistema eleitoral democrático e também a

\footnotetext{
${ }^{19} \mathrm{O}$ autoritarismo e o nacionalismo dos integralistas aproximaram-nos dos governos de Getúlio Vargas. Porém, apesar de o Estado Novo instituído em 1937 ter o centralismo na instituição estatal e o extremo autoritarismo como características, os integralistas foram perseguidos durante a ditadura de Vargas, que extinguiu os partidos. A partir desse momento, os integralistas não conseguiram mais se organizar com a mesma força, sendo hoje um movimento político residual que busca espaço no cenário brasileiro.
} 
prerrogativa pluripartidária, havendo "a criação de novas possibilidades de atuação para diversas tendências políticas existentes no período", 20 inserindo-se neste contexto "o neointegralismo e outros movimentos e organizações da direita brasileira” (NETO, 2012, p.148). Simultâneo a isto, o discurso negacionista passaria a ser usado como um dos recursos para se criar um ambiente de maior aceitação da direita - quando se nega, por exemplo, as formas de violência pela ditadura militar no Brasil, descolando-a dos mecanismos de repressão - e desse modo manter suas representações positivas no imaginário popular. ${ }^{21}$ Em síntese, há uma diversidade da direita no cenário brasileiro atual:

Há, desde o início da década de 2010, um crescimento da direita no Brasil. Esse fenômeno seria contemporâneo do avanço da extrema-direita na Europa e nos EUA e seria uma evidência a mais da guinada conservadora das democracias ocidentais a partir do início do século XXI. Todavia, no Brasil esse processo é extremamente complexo porque, a par da antiga direita ligada aos partidos tradicionais vinculados ao regime ditatorial-militar, como o DEM (o novo nome do PFL) e o PP (antigo PPB, PDS e Arena) -, há ao menos três factos novos: a ascensão de uma direita religiosa com o aumento numérico da "bancada evangélica" na Câmara dos Deputados, o surgimento de uma direita tipicamente liberal, em economia e em costumes, representada seja pelo NOVO, seja por uma corrente que disputava a hegemonia no PSL, os livres; e por último, mas não menos importante, a ascensão de movimentos sociais conduzidos por novas lideranças políticas de fora do establishment político tradicional, como o Movimento Brasil Livre (MBL). (BERLATTO, BOLONGNESE, CODATO, 2018, p.2). (Grifos nossos).

Para entender por que os evangélicos se identificam com a direita política e também porque aderiram à figura de Bolsonaro, é preciso ir além da análise "reducionista que supõem que o presidente recebeu votos dos evangélicos porque pastores mandaram seus fiéis votarem nele. Isso ocorre, mas é apenas um elemento de um processo mais amplo e complexo" (CUNHA, 2019, p.2), fazendo-se necessária, portanto, a percepção de outros elementos associados a um imaginário de longa duração histórica. Neste sentido, são apontados a seguir três exemplos que configuram estas representações.

\footnotetext{
${ }^{20}$ Neste período também ocorre "o crescimento daquele que veio a ser um referencial da direita brasileira pósditadura no âmbito das agremiações políticas: o PRONA (Partido de Reedificação da Ordem Nacional), fundado pelo médico cardiologista Enéas Ferreira Carneiro"'. Entre as bandeiras de sua militância, estavam: "um discurso ultranacionalista, adepto de um nacionalismo orgânico, contra a submissão do Brasil a órgãos internacionais e em defesa da família cristã; contra o aborto e união civil homossexual" (NETO, 2012, p.161).

${ }^{21}$ Tendo sido a ditadura militar brasileira um fenômeno de direita, consequentemente isto teria gerado a posteriori alguma dificuldade aos movimentos, organizações e diversos grupos da direita radical e extremista brasileira surgida após aquele regime, no qual se insere o fenômeno neointegralista, visto que, ao menos oficialmente, buscava-se superar aquele capítulo da história brasileira marcado pela direita (NETO, 2012, p.148).
} 
Primeiro, a representação da direita como algo positivo no imaginário evangélico, associada a princípios e valores tradicionais. Consolidou-se uma identificação da direita com o bem, com o que é moralmente correto. Tornou-se sinônimo de conservadorismo e aspectos considerados "tradicionais", que se definem na preservação de princípios bíblicos em relação ao modo de educar os filhos, do casamento heteroafetivo, do modelo de família nuclear:

Na deriva da expansão pentecostal, vicejou uma direita cristã antipluralista, afinada com traços da congênere norte-americana, que, localmente, articula retórica antiesquerdista e anticomunista com teorias conspiratórias e persecutórias contra o que rotula de "bolivarianismo", "marxismo cultural", "ideologia de gênero", vistas como ameaças à liberdade religiosa, aos valores cristãos e à "família tradicional". (GIRARDI; MARIANO, 2019, p.332).

Em contrapartida, para esse mesmo imaginário o que se vincula à esquerda está associado ao mal, ao ateísmo e a questões morais indevidas:

Apesar de o PT não ser um partido que tenha uma agenda comunista ou socialista, os evangélicos imaginam que a esquerda é comunismo, e comunismo é algo ateu, contrário à família. Essa é a visão preponderante. É uma visão simples de associar um selo. Esquerda, então comunista. Comunista, então ateia. Ateia, contra a família e pró-união homoafetiva e aborto, por exemplo. (VELOSO, 2018, p.6).

Tais aspectos podem ser dimensionados nas palavras de Ana Paula Valadão - líder da Igreja Batista de Lagoinha, de Belo Horizonte, e vocalista da banda Diante do Trono, uma das mais famosas e influentes da música gospel -, quando durante a campanha eleitoral para presidente, em 2018, conclamou fiéis e seguidores por meio de vídeo no Youtube a votarem a "favor dos princípios bíblicos e da direita", argumentando que era seu dever assim proceder para "um livramento da nação brasileira":

Vim aqui reforçar que eu e você temos que nos posicionar hoje a favor dos princípios bíblicos. [...] Você deve estar fazendo valer o seu voto contra essas enxurradas de maldições, de malignidades [...] É hora de você fazer o seu voto valer, não apenas votar em alguém que você gosta, com essa ou aquela proposta, mas votar em quem vai derrubar a esquerda deste país. Se você prestar atenção, a gente precisa votar no Bolsonaro, para que ainda no primeiro turno a gente acabe com essa discussão. Porque se houver segundo turno, existe uma grande possibilidade do PT voltar ao poder. Mesmo que haja outros candidatos com que você se identifique, vote raciocinando da seguinte forma: "Eu preciso tirar essa esquerda podre do governo do país. E eu vou votar no Bolsonaro porque ele é o único que tem a chance de vencer no primeiro turno". Vote também nos dois candidatos a senadores do seu estado, de forma a apoiar a direita, que são os representantes dos princípios cristãos, princípios conservadores. (VALADÃO (a), 2018). (Grifos nossos). 
Essa visão está tão presente na vivência religiosa evangélica que até mesmo relatos bíblicos são lidos a partir desta polaridade. O texto do evangelho, por exemplo, que menciona a crucificação de dois ladrões ao lado de Jesus - "Quando chegaram ao lugar chamado Calvário, ali o crucificaram, bem como aos malfeitores, um à direita, outro à esquerda" (Lc 23:33) - é comumente interpretado identificando-se o "bom ladrão" - que se arrependeu e recebeu a promessa do paraíso, nominado pela tradição como "Dimas", vindo inclusive a se tornar santo no catolicismo - como aquele que estava do lado "direito de Jesus". O outro, por sua vez, o "mau ladrão", é visto como incrédulo e rebelde, identificado como aquele que estava "à esquerda”. A afeição dos evangélicos com a figura de Bolsonaro passa por esta dimensão do imaginário; ele soube se aproximar deste universo representacional: "O sucesso do discurso de Bolsonaro se deve quase que integralmente a sua intuição de capitalizar a potencialidade existente na maioria dos evangélicos brasileiros para ações políticas de direita" (CAMPOS, 2019, p.360). Enquanto ainda candidato, em entrevista ao programa Roda Viva, afirmou: "Nós queremos um redirecionamento do Brasil no tocante à sua política; nós cansamos da esquerda, queremos um país liberal, que respeite a família e nossas crianças na sala de aula, que jogue pesado contra o MST" (RODA VIVA, 2028).

Um segundo aspecto a se destacar, é a fantasmagoria do comunismo que continua a assombrar o imaginário evangélico. A queda simbólica do Muro de Berlim, em 1989, foi celebrada como vitória sobre o comunismo, representante do reino do anticristo. Mas logo se direcionou a atenção para outras facetas insurgentes de um inimigo a ser combatido: os partidos de esquerda, que abraçaram pautas a favor de temas polêmicos em relação à família, aborto, criacionismo, gênero, homossexualidade, movimento feminista e liberação de tipos de drogas. Essas matérias despertaram paixões e providenciaram um tipo de justificativa para uma presença religiosa ainda mais ostensiva na trincheira política de direita, numa espécie de barreira de contenção. O depoimento de Silas Malafaia dimensiona estas representações: "O grande erro da esquerda foi ter ido com muita sede ao pote para apoiar os temas morais que o cristão rejeita. Aborto, ideologia de gênero, casamento gay, liberação de drogas" (ABBUD, 2018, p.2).

Este cenário instiga a mobilização para um enfrentamento ou "guerra espiritual" contra o mal, nisto identificados governos de esquerda, em um mundo polarizado entre sacralização e demonização: 
A campanha antipetista evangélica não se restringiu a acusar grupos, partidos, parlamentares, governos e candidatos do PT e de esquerda de serem comunistas, anticristãos, imorais e inimigos do Evangelho. Sacralizou candidatos e partidos conservadores e de direita, identificando-os como representantes políticos dos princípios cristãos e de Deus. (GERARDI; MARIANO, 2019, p.344).

Esse medo da esquerda leva, por sua vez, à projeção e apego a líderes salvacionistas. A posição anti-esquerda ficou evidenciada, por exemplo, nos argumentos de apoio absoluto ao candidato de direita na última eleição presidencial. O deputado federal Hidekazu Takayama (PSC/PR), pastor da Assembléia de Deus e presidente da Frente Parlamentar Evangélica (FPE), que reúne 199 deputados e 4 senadores, pouco antes do primeiro turno oficializou apoio da bancada a Bolsonaro, ressaltando que "o grupo entende que Bolsonaro é o nome mais adequado para lutar pelas pautas de seus integrantes", acrescentando que "nosso intuito é evitar que candidatos filiados a extrema esquerda assumam, mais uma vez, a direção do país" (ESTADÃO, 2018, p.1). Alegou ainda ter apoiado o impeachment de Dilma “porque estávamos a um passo de nos tornarmos uma Venezuela", fazendo um alerta:

Infelizmente, o Brasil está se tornando um país de esquerda ateia. Vivemos no limite do perigo, pois, eles, os ateus, não gostam de nós, cristãos, e farão de tudo para prejudicar as famílias cristãs e as igrejas. O que está em jogo é a liberdade de se pregar o evangelho. (GERARDI; MARIANO, 2019, p.340).

Líderes de cariz fascista se caracterizam por projetar inimigos a serem derrotados, explorando o medo da população frente a uma ameaça ou contexto de instabilidade. Sua força simbólica é muito mais representativa quando revestida do elemento religioso, como alerta Umberto Eco:

Mussolini não tinha qualquer filosofia: tinha apenas uma retórica. Começou como ateu militante, para em seguida assinar a concordata com a igreja e confraternizar com os bispos que benziam os galhardetes fascistas. Em seus primeiros anos anticlericais, segundo uma lenda plausível, pediu certa vez que Deus o fulminasse ali mesmo para provar que existia. Evidentemente, Deus estava distraído. Nos anos seguintes, em seus discursos, Mussoloni citava sempre o nome de Deus e não se importava de ser chamado de homem da Providência. (ECO, 2002, p.9). (Grifos nossos).

Parte da visão evangélica sobre questões sociais é marcada pela ideia de uma sociedade em permanente ameaça quanto aos valores chamados de conservadores ou tradicionais, como uma arena na qual se trava uma luta do bem contra o mal, instando os fiéis a se engajarem em um enfrentamento. Nesta sociedade, vista como um cenário de permanente ameaça, os evangélicos se veem convocados a se colocar no front. Disto decorre um apreço por instituições fortes que 
no imaginário simbolizam ordem e defesa, como é o caso do exército. Nota-se essa identificação na linguagem bélica ou militarizada presente expressa na música gospel popularizada que, em estilo ritmado ao som de bandas, embala a juventude em seus diversos eventos espirituais. Versos que associam a igreja a um "exército", em "plano guerra", que se utiliza de "arma" (CAMPOS, 1990); ${ }^{22}$ frases que identificam Deus à "guerra", aquele que vence os seus "inimigos" e concede "poder para guerrear" (CAMPOS, 1992); ${ }^{23}$ letras que falam de "batalha" (CAMPOS, 1994). ${ }^{24}$ Outra canção também destaca as palavras "arma", "batalhão", "adestramento" e preparo "para guerrear", denotando inclusive requinte de violência contra os “inimigos", que são "perseguidos", "consumidos" e "atravessados” (simbolizando a espada que transfixa) (BORBA, 1985). ${ }^{25}$ Por fim, outra letra na qual a linguagem é novamente "militarizada", com emprego dos termos "guerra", "batalha", "arma de guerra", "peleja", “exércitos" (DIANTE DO TRONO, 2017). ${ }^{26}$

Nota-se, sobretudo entre os neopentecostais, uma predileção pela leitura e prédica de textos do Antigo Testamento, onde é mais recorrente o uso deste vocabulário; pouco se fala ali do Novo Testamento, exceto do livro do Apocalipse, no qual estilisticamente também é enfática a noção de ameaça e o convite ao enfrentamento de inimigos. Isto ajuda a entender, em parte, a ênfase nesse perfil de musicalidade. Tal linguagem também permite compreender melhor, por exemplo, a interatividade entre Bolsonaro e o público evangélico quando imita com as mãos uma arma nos eventos de que participa, assim como durante o pleito eleitoral para presidente,

\footnotetext{
${ }^{22}$ A música tem como título Exército de Deus, interpretada por Adhemar de Campos. Em seu refrão diz: "Eu posso escutar /O exército de Deus /marchando sobre a terra /Em plano de guerra vai /Já ouço o louvor que é a arma de vitória/ O exército de Deus /O exército de Deus /O exército de Deus /Marchando vai!" (CAMPOS, 1990). (Grifos nossos).

${ }^{23}$ A música tem como título Homem de Guerra, interpretado por Adhemar de Campos. Em seu refrão diz: "Homem de guerra é Jeová,/ Seu nome é temido na Terra /A todos os seus inimigos venceu /Deus grande e temido em Louvores /Quem é como o Senhor /Entre os deuses sobre a terra /Que me livra do mal /Que me dá poder para guerrear". (CAMPOS, 1992). (Grifos nossos).

${ }^{24}$ A música tem como título Nosso general, interpretada por Adhemar de Campos. Em seu refrão diz: "Pelo senhor marchamos sim/ O seu exército poderoso é/ Sua glória será vista em toda a terra/ Vamos cantar o canto da vitória/ Glória a Deus, vencemos a batalha/ Toda arma contra nós perecerá/ O nosso general é Cristo/ Seguimos os seus passos/ Nenhum inimigo nos resistirá [...]". (Grifos nossos).

${ }^{25}$ A música tem como título O Caminho de Deus É Perfeito, interpretada por Asaph Borba. Sua letra diz: "O Caminho de Deus é perfeito/ Na palavra do Senhor há poder/Ele é a arma, o escudo de todos os que nele confiam/ Ele é a minha fortaleza e a minha força/ Com ele passo pelo meio de um batalhão/ Ele adestra minhas mãos, me prepara para guerrear/ Porque quem é Deus senão o Senhor/ E quem é o rochedo senão nosso Deus /Aleluia, aleluia, aleluia, aleluia/ Persegui os inimigos e os alcancei/ Os consumi e os atravessei/ Sob os pés do senhor caíram/ Não mais se levantaram". (BORBA, 1985). (Grifos nossos).

${ }^{26}$ A música tem como título Senhor dos Exércitos, Rei, interpretada pelo grupo Diante do Trono. Em seu refrão diz: "[...] Guerreia por mim/ Glorioso Senhor, Poderoso nas batalhas/ Tu és o meu escudo e arma de guerra/ Envia teus anjos pra pelejar/ Em meu favor nesta batalha/ Tu és o Senhor dos exércitos, Rei/ [...]”. (DIANTE DO TRONO, 2017). (Grifos nossos).
} 
em que sua imagem era por esse gestual representada: "não é difícil encontrar o nome de Deus ao lado de imagens de fuzis AR-15 estampados nas camisetas vendidas por apoiadores do candidato durante a campanha" (ÉPOCA, 2018, p.4). Ele assim se comunica eficazmente, transmitindo uma mensagem revestida de significados e familiaridade a integrantes deste grupo. Comporta-se como um agente que, não obstante à fase inicial de socialização ou configuração de um habitus ${ }^{27}$ neste subcampo religioso, demonstra habilidade em relação às regras nele existentes:

A retórica de Bolsonaro, tal como a neopentecostal, é dualista e belicosa. Ele faz das palavras armas de guerra. No seu discurso há sempre um ataque contra a "esquerda" responsabilizada pela crise econômica, política, social, e moral que atualmente abala o Brasil. As suas cruzadas podem ser resumidas na expressão "Deus o quer", "Deus está conosco" ou "Se Deus é por nós, quem será contra nós?”. (CAMPOS, 2019, p.360).

Portanto, o contexto brasileiro que projetou Bolsonaro foi marcado pela desconfiança da política ou das instituições políticas, gerando a necessidade de atuação de um líder salvacionista, capaz de fazer o enfrentamento. Neste sentido, no ambiente evangélico são valorizadas figuras que demonstrem autoridade e um poder simbólico divinamente concedido, vistas como emissários para reestabelecer a ordem, trazer proteção à nação e à família ou derrotar inimigos do povo crente, reeditando representações dos tempos bíblicos. Conforme conceitua Bourdieu (2002, p.154), essa projeção do fascínio pessoal do líder é coletivamente atribuída pelo grupo, por sintetizar e responder positivamente a seus anseios e expectativas que, às vezes, estão latentes em uma maioria silenciosa. ${ }^{28}$ Exemplificando, no caso de Bolsonaro, “ele se apresenta como um escolhido pela divindade para captar as esperanças e decepções dos desiludidos da política. Julga-se capaz de transformar o desespero em esperança" (CAMPOS, 2019 , p.362). Sobre isso ele declarou: "não falo o que o povo quer, sou o que o povo quer" (FOLHA DE S.PAULO, 2016). Desse modo, representando uma "nova direita" e uma "nova política" - frente ao desgaste da esquerda - Bolsonaro é para seus leitores um dos poucos políticos honestos do Brasil, tendo a missão de proteger a população da violência, defender a família e salvar o país da "ameaça comunista".

\footnotetext{
${ }^{27}$ De acordo com Bourdieu, o habitus consiste em disposições adquiridas ou incorporadas que orientam o comportamento dos que agem no interior de um dado campo. (BOURDIEU, 1996 (b), p. 158).

${ }^{28}$ Como exemplo, a figura de Bolsonaro: "Ele exerceu cargo de deputado a quase $1 / 4$ de século; não foi eleito no período da ditadura, mas no florescer da abertura democrática; foi eleito pelo Rio de Janeiro por 7 mandatos, um estado com os maiores índices de escolaridade, sendo 464 mil votos na última eleição para deputado; logo ele não é sozinho o bastião da direita, ele precisa de uma plateia direitista que o eleja, e essa plateia é numerosa" (KARNAL, 2018).
} 
E, por fim, como um terceiro vetor, a concepção de uma "teologia do domínio", também chamada dos "sete montes". Essa visão teológica está relacionada à criação de organizações para a difusão de valores da "cultura cristã" em diferentes setores da sociedade, com o objetivo de assegurar o conservadorismo cultural pautado em elementos da crença e disseminar de uma visão cultural-religiosa de direita. Sua origem se dá por meio de um movimento denominado "teologia do domínio" ou "teologia dos sete montes". ${ }^{29}$ A simbologia dos montes se refere ao papel da igreja em ser responsável por estabelecer princípios da fé cristã nos diversos setores da sociedade, posicionando-se "no cume dos montes para dessa forma influenciar a sociedade", adotando para isso "uma mentalidade de conquista, com o propósito de alcançar a qualidade de ser cabeça de toda cultura" (GUILLEN, 2000, p.6). Parte-se da seguinte argumentação:

Hoje, o controle de várias das esferas mais influentes está nas mãos da esquerda secular, especialmente na educação e na mídia. Ainda há resistência na área dos negócios e no campo político. Os mestres desse ensino das sete montanhas estão encorajando os cristãos e judeus messiânicos a abraçar os chamados em cada uma dessas sete esferas para mudar a direção de toda a cultura. (REVISTA IMPACTO, 2015, p.2). (Grifos nossos).

Esse movimento surgiu com a criação nos anos 1990 da Capitol Ministries (Ministério do Capitólio) $)^{30}$ - símbolo do Congresso americano - com a finalidade de desenvolver um cristianismo aplicado à política, ou seja, “converter” políticos e servidores públicos a uma visão cristã evangélica da política, alinhada à ultradireita americana. Com isso, busca-se promover os valores conservadores, controle e ordem, defesa dos princípios morais cristãos tidos corretos em relação, por exemplo, a temas como casamento e aborto. $\mathrm{O}$ discurso feito nas mídias sociais e as conferências têm sido caracterizados por polêmicas, como é caso de se posicionar a favor da guerra e do negacionismo em relação ao aquecimento global. Desde 2018, a organização expandiu suas atividades em cinco países latino-americanos ${ }^{31} \mathrm{e}$, mais recentemente, no Brasil, com atividades religiosas junto ao Senado, Câmara, aproximando-se também do presidente Bolsonaro e outros integrantes de seu governo. ${ }^{32}$ Algumas igrejas têm disseminado essa visão por meio de publicações, realizando workshops com líderes nacionais, visando ocupar lugares

\footnotetext{
${ }^{29}$ Uma referência simbólica para identificar sete áreas: artes e entretenimento; mídia e comunicação; governo e política; educação e ciência; família; economia e negócios; igreja e religião. Ver livro: GUILLEN, Fernando. Sete montes. Macaé: Editora Sete Montes, 2000.

${ }^{30}$ Criado pelo pastor Ralph Drollinger, ex-jogador de basquete, na Califórnia.

${ }^{31}$ México, Honduras, Paraguai, Costa Rica e Uruguai.

${ }^{32}$ Sob liderança de Raul Ferreira, pastor da Igreja Batista Vida Nova, de Brasília, que recebeu treinamento nos Estados Unidos.
} 
estratégicos em diferentes áreas da sociedade. ${ }^{33}$ Uma ramificação do Capitol Ministries surgiu em 2001, com a criação do The Call Ministries (Ministério A Chamada), pelo pregador norteamericano Lou Eagle. ${ }^{34}$ Voltado prioritariamente à juventude, esse movimento promove eventos evangélicos em estádios, com shows musicais, orações e pregações religiosas com foco em questões morais e culturais, reunindo centenas de milhares de pessoas, atraindo participantes de vários países. Permeado por discursos de uma cultura comportamental conservadora - organizando, por exemplo, protestos públicos contra o direito ao aborto e as relações homoafetivas - o movimento alcançou a simpatia da direita cristã americana. Em 2016, em um dos eventos realizados pelo The Call, no estádio Los Angeles Memorial Coliseum, o pregador fez um apelo aos presentes: “Tirem seus sapatos e levantem para o céu se estiverem dispostos a ir a qualquer lugar do mundo para expandirem a mensagem do evangelho. Foram 70 mil pares de sapato no ar”. Nascia, assim, o The Send (O Envio), com a missão de expandir aquela mobilização. Três principais frentes de atuação foram definidas: as mídias sociais, reunindo virtualmente os jovens identificados como "webcrentes"; as universidades; realização de eventos em estádios com músicas e workshops (THE SEND BRASIL, 2021). ${ }^{35}$

Como plano de expansão para a América Latina, o Brasil foi escolhido como a primeira sede de um grande impacto do The Send, o que ocorreu em fevereiro de 2020, com a realização de três encontros, dois em São Paulo e um em Brasília, em três estádios de futebol lotados, com a presença de milhares de jovens. ${ }^{36}$ Marcaram presença nestas edições pregadores norte-

\footnotetext{
${ }^{33}$ Igrejas influentes, como a Batista da Lagoinha, em Belo Horizonte, têm investido nesta propagação, utilizando como nomenclatura "Visão dos Sete Montes".

34 Lou Engle é um líder evangélico americano, conhecido por defender que questões como aborto e homossexualidade devem permanecer no centro das pautas de enfrentamento pelo movimento evangélico. Seus simpatizantes militam para que evangélicos votem em candidatos políticos "pró-vida". Assumindo uma posição firme em questões tradicionalmente associadas à direita cristã, os eventos de Engle atraíram o apoio de líderes evangélicos nos diversos escalões da política americana. Atualmente, Lou é o responsável pela implantação de diversos núcleos desse movimento em várias partes da América do Norte e Latina.

${ }^{35}$ Em seu site oficial, no Brasil, o The Send se define como um "movimento missionário", que reúne missionários internacionais e líderes de diferentes "organizações” evangélicas de várias igrejas; viaja o mundo se apresentado em grandes estádios, para realização de palestras, pregações, músicas e orações, tem a missão de incentivar os jovens a expandir a mensagem evangélica para não-evangélicos, com duração de 12 horas em cada evento. (THE SEND BRASIL, 2020).

${ }^{36}$ Cerca de 80 mil jovens participaram nos eventos em cada uma das cidades. Em 2018, ano em que foram realizadas as últimas eleições no Brasil, houve aumento na porcentagem de jovens de 16 e 17 anos que tiraram título de eleitor. Segundo dados analisados pelo jornal Folha de S. Paulo a partir de números divulgados pelo IBGE (Instituto Brasileiro de Geografia e Estatística) e pelo TSE (Tribunal Superior Eleitoral), 29,5\% desta faixa etária se encontrava apta para votar. O que corresponde a 250 mil novos eleitores. Houve um aumento em comparação a 2014, eleição que elegeu Dilma Rousseff, quando foi registrada a porcentagem de 23,9\%. O interesse de jovens, de acordo com especialistas ouvidos pela Folha, tem relação com a forte presença deste público em redes sociais, ambiente em que políticos divulgam suas propostas, repercutem notícias e fazem pronunciamentos em tempo real, por meio de lives. (BEREIA, 2020).
}

REVISTA RELEGENS THRÉSKEIA - 2021 - UFPR 
americanos, líderes evangélicos nacionais e as bandas de música gospel mais conhecidas no país. Em Brasília, o evento teve a presença do presidente Bolsonaro. ${ }^{37}$ No palco, ele cumprimentou a plateia, chamando-a de "ponto de inflexão" nas eleições de 2018; "Vocês decidiram, vocês mudaram o destino do Brasil. Devo a Deus a minha vida, devo a vocês a missão de dar um norte para o destino do nosso Brasil". Também voltou a dizer que "o Estado pode ser laico", mas que ele é cristão, arrancando aplausos da multidão. E acrescentou: "Estou aqui porque acredito no Brasil e nós estamos aqui porque acreditamos em Deus. O Brasil mudou. Palavras antes proibidas começaram a se tornar comuns: Deus, família, pátria. Somos um só povo, uma só raça". ${ }^{38}$ E finalizou:

Ninguém esperava uma pessoa da minha origem e da minha atividade política conseguir vencer esse verdadeiro mecanismo, mais conhecido como establishment. Vocês fizeram diferença. Hoje, temos um governo que respeita os valores familiares, deve lealdade a seu povo e é temente a Deus. (METRÓPOLES, 2020, p.2).

Comentando o simbolismo dessa participação, Henrique Krigner $^{39}$ - jovem líder do The Send no Brasil - publicou em sua conta nas redes sociais:

Bolsonaro desceu as escadas com lágrimas nos olhos dizendo "estou sendo muito tocado. Posso dar uma palavra?". Foram essas as palavras que ele usou e, diante disso, cedemos o espaço. [...] qualquer outro que com olho marejado nos fizesse esse pedido nós daríamos o mesmo espaço. É o momento que sai a "figura pública" e entra o ser humano por detrás do título. Foi lindo e agradeço a Deus por ter sido parte desse episódio que pra mim marca uma nova forma de impacto e influência na relação de crentes com líderes públicos. (BEREIA, 2020, p.3)

Ocupando guarida neste imaginário da teologia do domínio, a bancada evangélica, no Congresso Nacional, convicta de sua superioridade moral, de seus projetos e de sua missão política, batalha para estender a ocupação no legislativo, nos meios de comunicação e nas decisões das políticas públicas, buscando inserir suas crenças e valores na normatividade jurídica e no ensino. Seus parlamentares são os principais proponentes dos projetos de lei da chamada "escola sem partido" - relacionado às pautas da moralidade sexual - e também à

\footnotetext{
${ }^{37}$ Damares Alves, pastora e ministra da pasta da Mulher, Família e Direitos Humanos, também participou do evento como uma das preletoras.

${ }^{38}$ Note-se a referência a termos que caracterizam o Integralismo, conforme anteriormente destacado neste artigo.

${ }^{39}$ Em suas páginas nas mídias sociais, mantém posicionamentos políticos em defesa da direita: nas eleições de 2018, afirmou: "Pela primeira vez a Igreja se reuniu em torno de um candidato em termo de presidência para votar [...] é uma reação à máquina que foi implantada no país"; oposição ao Movimento Lula Livre; crítica ao Supremo Tribunal Federal (STF), ao refletir sobre prisão e votação em segunda instância, referindo-se ao caso do expresidente Lula; intitula uma de suas páginas de República de Curitiba (em apoio alusivo à Operação Lava-Jato); foi candidato a vereador por São Paulo, nas eleições de 2020. Para mais detalhes, ver: <https://www.facebook.com/RepublicaDeCuritibaBR/> Acesso em: 3 ago. 2021. 
imposição de um tipo de censura à atuação de educadores nas escolas, além da tentativa de influência e direcionamento sobre os materiais didáticos.

Essa inserção de evangélicos em setores estratégicos também se espelhou no governo Bolsonaro, pelas nomeações que fez aos cargos de primeiro e segundo escalões: o Ministério da Casa Civil, inicialmente sob comando do luterano Onyx Lorenzoni; o Ministério do Turismo, conduzido pelo membro da Igreja Maranata Marcelo Álvaro Antônio; o ministro-chefe da Secretaria de Governo, general Luiz Eduardo Ramos, que é batista. Alguns são pastores: Damares Alves, pastora da Igreja Quadrangular (Ministério da Mulher, Família e Direitos Humanos); André Mendonça, pastor presbiteriano (por um tempo, no Ministério da Justiça e Segurança Pública, por outro, como Advogado Geral da União); Milton Ribeiro, pastor presbiteriano (Ministério da Educação); Sérgio Queiroz (que integra a equipe ministerial de Damares Alves como secretário nacional de proteção global), é pastor da igreja Cidade Viva, em João Pessoa - PB. E, ainda, para ocupar a vaga aberta para ministro no Supremo Tribunal Federal (STF), Bolsonaro prometeu indicar um ministro "terrivelmente evangélico"40 (O GLOBO, 2021), fato que ocorreu com indicação de André Mendonça, em dezembro de 2021, sendo aprovado pelo Senado para ocupar o referido cargo.

\section{Considerações finais}

É importante dizer que, nem todos os evangélicos são de direita e nem todos votaram em Bolsonaro para presidente. Mas abordar a identificação evangélica com a política de esquerda foge, no momento, aos limites deste artigo. No que diz respeito à sua identificação com a política de direita, as análises aqui apresentadas demonstraram a importância dos elementos simbólicos, dos imaginários e crenças para se interpretar como isto se construiu. Um contexto de incertezas e instabilidade, na última década, potencializou a necessidade de um líder carismático ou salvacionista, conforme Bourdieu: "quando a ordem estabelecida ameaça romper-se ou quando o futuro inteiro parece incerto", surge o "homem de situações extraordinárias", com a missão de reordenar o mundo percebido como caótico (BOURDIEU, 2011, p.73,74). Para isso, seu discurso é articulado a um determinado grupo social e a um capital simbólico acumulado no campo, do qual deriva seu poder. Ao trazer à realidade cotidiana mitos

\footnotetext{
${ }^{40}$ Expressão usada por Jair Bolsonaro em culto evangélico realizado na Câmara dos Deputados, em 10/07/19, referindo-se à indicação que pretende fazer para a ocupação da próxima vaga a ser aberta no STF. O critério religioso para a nomeação foi destacado em reportagem recente do jornal $O$ Globo, em matéria publicada com o seguinte título: "Três evangélicos disputam vaga que será aberta no STF em julho". Disponível em: https://g1.globo.com/politica/noticia/2019/07/10/; oglobo.globo.com Acesso em: jan. 2021.
} 
e imagens colhidos no imaginário, ele atinge seus objetivos (CAMPOS, 2019, p.364). Foi assim que o antigo sonho acalentado por um grupo religioso de eleger um mandatário político como seu representante parece ter finalmente se realizado, ainda que por meio de um "quase evangélico": "Foi muito caro a muitos evangélicos imaginar ter no poder maior do país alguém defensor de suas pautas, como 'homem simples, do povo, que fala o que pensa' e isto parece ter sido um propulsor do voto que descarregaram em Bolsonaro" (ÉPOCA, 2018, p.3). No cenário político emergente, pavimentou-se uma pista de mão dupla, do púlpito aos palanques, havendo uma sacralização do político e uma politização do sagrado; o atual presidente da República soube transitar nesta via. Projetou-se como capaz de derrotar o inimigo petista e os perigos a ele associados, de livrar o país do comunismo, de assegurar o direito aos pais de educarem seus filhos, evitando assim uma reorientação sexual das crianças, de impedir a destruição da família em seu modelo considerado tradicional. Conseguiu assim reunir seguidores em torno de uma figura revestida de missão divina para reestabelecer a ordem social.

A história mantém dessa forma seu dinamismo, quando o presente é revisitado pelo passado e os campos - político e religioso - são capazes de operar transfigurações aparentemente ilógicas ou contraditórias em relação ao atual governante do país: um deputado de sete mandatos, que se projetou como oposição à "velha política"; um presidente que apregoa combater a violência liberando o uso de armas, obtendo apoio de milicianos; um admirador de torturadores da ditadura, que afirma proteger a democracia; um governante que criminaliza trabalhadores rurais por ocuparem terras de reforma agrária, mas que flexibiliza a invasão de territórios indígenas para ampliação de latifúndios do agronegócio; um defensor da família tradicional e conservadora, que já se casou três vezes; um líder com traços fascistas, que empunha a bandeira de Israel e toma partido a favor de judeus; um católico confesso, que é aclamado por evangélicos como um mito.

Há sinais de um avanço da direita sobre a esquerda, do autoritarismo sobre a democracia, da belicosidade sobre o pacifismo, do negacionismo sobre a evidência, do obscurantismo sobre a ciência. Daí serem alertadoras as palavras de Umberto Eco, com as quais finalizamos esse texto:

Devemos ficar atentos, para não esquecer, para não dar esse mal como superado; o fascismo eterno ainda está ao nosso redor, às vezes em trajes civis [...]. Nosso dever é desmascará-lo e apontar o indicador para cada uma de suas novas formas - a cada dia, em cada lugar do mundo. (ECO, 2002, p.1). 


\section{REFERÊNCIAS}

ABBUD, B. Como Bolsonaro se tornou o candidato dos evangélicos. Época, Rio de Janeiro, Editora Globo, 06/10/2018. Disponível em: <https://epoca.globo.com/como-bolsonaro-setornou-candidato-dos-evangelicos-23126650>. Acesso em: 20 jan. 2021.

ALVES, J. E. D. O voto evangélico garantiu a eleição de Jair Bolsonaro. 2018. Disponível em: $<$ https://www.ecodebate.com.br/2018/10/31/o-voto-evangelicogarantiu-a-eleicao-de-jairbolsonaro-artigo-de-jose-eustaquio-diniz-alves/>. Acesso em: 15 jan. 2021.

ALMEIDA, Ronaldo R. M. A universalização do Reino de Deus. Novos Estudos CEBRAP, São Paulo, n. 44, 1996.

ARAÚJO, João Dias de. Inquisição sem fogueiras: 20 anos de história da Igreja Presbiteriana do Brasil (1964-1974). Rio de Janeiro: Instituto Superior de Estudos da Religião, 1976.

BATISMO da filha de Bolsonaro. Uol, Rio de Janeiro, 2020. Disponível em: <https://www.bol.uol.com.br/noticias/2020/11/07/filha-jair-bolsonaro-laura-batismo-igrejaevangelica-brasilia-michelle.htm?cmpid=copiaecola>. Acesso em: 25 jan. 2021.

BASSO, Marina Lacerda. O novo conservadorismo brasileiro: de Reagan a Bolsonaro. Rio de Janeiro: Zouk, 2019.

BEREIA. Informação e checagem de notícia. Movimento The Send Brasil é criticado por doutrinar politicamente jovens evangélicos. 2020. Disponível em: $<$ https://coletivobereia.com.br/movimento-the-send-brasil-e-criticado-por-doutrinarpoliticamente-jovens-evangelicos/>. Acesso em: 3 fev. 2021.

BORBA, Asaph. O caminho de Deus é perfeito. 1985. Disponível em: <https://www.letras.mus.br/asaph-borba/172307/>. Acesso em: 28 jan. 2021.

BOURDIEU, Pierre. A produção da crença. Contribuição para uma economia dos bens simbólicos. São Paulo: Zouk, 2002.

As regras da arte. São Paulo: Companhia das Letras, 1996. (a)

. Razões práticas. Sobre a teoria da ação. Campinas: Papirus, 1996. (b)

. A economia das trocas linguísticas. São Paulo: EDUSP, 1996. (c)

. A economia das trocas simbólicas. São Paulo: Perspectiva, 2011.

Esboço de auto-análise. São Paulo: Companhia das Letras, 2005.

CALIL, Gilberto Grassi. Integralismo e hegemonia burguesa: a intervenção do PRP na política brasileira (1945-1965). Cascavel: Edunioeste, 2010. 
CAMPOS, Adhemar. O exército de Deus. 1990. Disponível em: <https://www.vagalume.com.br/ademar-de-campos/o-exercito-de-deus.html>. Acesso em: 30 jan. 2021

. Homem de guerra. 1992. Disponível em: <https://www.ouvirmusica.com.br/adhemarde-campos/1450011/>. Acesso em: 29 jan. 2021.

Nosso general. Interpretação musical: Adhemar de Campos. 1994. Disponível em: <https://www.ouvirmusica.com.br/adhemar-de-campos/1450011/>. Acesso em: jan. 2021.

CAMPOS, Leonildo Silveira. Teatro, templo e mercado. Organização e marketing de um empreendimento neopentecostal. Petrópolis: Vozes, 1997.

. Bolsonaro - mito político ou líder carismático?. In: CARRANZA, Brenda; GUADALUPE, José Luiz Pérez (Orgs.). Novo ativismo político no Brasil: os evangélicos do século XXI. Rio de Janeiro: Konrad Stiftung, 2020.

CAPELATO, Maria Helena. Multidões em cena. Propaganda política no varguismo e no peronismo. $2^{\text {a }}$. ed. São Paulo: Editora Unesp, 2008.

CARDOSO, Ciro Flamarion. História e poder: uma nova história política? In:

VAINFAS, Ronaldo (Orgs.). Novos domínios da história. Rio de Janeiro: Elsevier, 2012.

CAVALARI, Rosa Maria Feiteiro. Integralismo: ideologia e organização de um partido de massa no Brasil (1932 - 1937). Bauru: EDUSC, 1999.

CHARTIER, R. Pierre Bourdieu e a história. Topoi, Rio de Janeiro, URFJ, n. 4, 2002.

CODATO, Adriano; BERLATTO, Fábia; BOLOGNESE, Bruno. Tipologia dos políticos de direita no Brasil: uma classificação empírica. Análise Social, LIII, n. 229, p. 870- 897, 2018.

CUNHA, Magali. Bolsonaro é o presidente que adere, sobe no altar e dá vazão a pautas de evangélicos. Entrevista especial com Magali Cunha. São Leopoldo, Instituto Humanitas Unisinos, 23 set. 2019. Disponível em: <http://www.ihu.unisinos.br/159noticias/entrevistas/592752->. Acesso em: 20 fev. 2020.

Ciclo igrejas e ditadura: memória, verdade e utopia. Disponível em: <https://www.facebook.com/rreformada20/videos/502300777628137>. Acesso em: 10 abr. 2021.

DATAFOLHA. São Paulo, dez. 2020. Disponível em: <https://www1.folha.uol.com.br/poder/2020/01/cara-tipica-do-evangelico-brasileiro-efeminina-e-negra-aponta-datafolha.shtml>. Acesso em: 25 jan. 2021.

DIANTE DO TRONO. Senhor dos exércitos, rei. 2017. Disponível em: <https://www.letras.mus.br/diante-do-trono/283502/>. Acesso em: 26 jan. 2021.

ECO, Umberto. O fascismo eterno. Rio de Janeiro: Editora Record, 2019. 
ÉPOCA. Rio de Janeiro, Editora Globo, 06/10/2018. Como Bolsonaro se tornou o candidato dos evangélicos. Disponível em: <https://epoca.globo.com/como-bolsonaro-se-tornoucandidato-dos-evangelicos-23126650>. Acesso em: 10 dez. 2020.

ESEB. Campinas-SP, 2018. Disponível em: <https://www.cesop.unicamp.br/por/eseb>. Acesso em: 21 abr. 2021.

ESTADÃO. São Paulo, 4/8/2018. Bancada evangélica da Câmara oficializa apoio a Bolsonaro. Disponível em <https://politica.estadao.com.br/noticias/eleicoes, bancada-evangelicaoficializa-apoio-a-bolsonaro,70002532347>. Acesso em: 15 jan. 2021.

FINQUERUT, A. Formação, crescimento e apogeu da direita cristã nos Estados Unidos. In: SILVA, C. E. Lins da. (Org.). Uma nação com alma de Igreja. São Paulo: Paz e Terra, 2009.

FOLHA de S.Paulo. São Paulo, 9/6/2016.

FOLHA de S.Paulo. São Paulo, 2/9/2019.

FONTES, Virgínia; MENDONÇA, Sonia Regina de. História e teoria política. In: CARDOSO, Ciro Flamarion; VAINFAS, Ronaldo (Orgs.). Novos domínios da história. Rio de Janeiro: Elsevier, 2012.

FRESTON, Paul. Protestantes e política no Brasil: da Constituinte ao Impeachment.1993. Tese (Doutorado em Ciências Sociais) - Universidade Estadual de Campinas, Campinas, 1993.

FREYRE, Gilberto. Casa grande \& senzala: formação da família brasileira sob o regime da economia patriarcal. 50. ed.. São Paulo: Global, 2005.

GERARDI, Dirceu André; MARIANO, Ricardo. Eleições presidenciais na América Latina em 2018 e ativismo político de evangélicos conservadores. Revista USP, no 120, 2019, p. 61-76.

GUILLEN, Fernando. Sete montes. Macaé: Editora Sete Montes, 2000.

G1. Política, 10 jul. 2019. Bolsonaro diz que vai indicar ministro "terrivelmente evangélico" para o STF. Rio de Janeiro, 2029. Disponível em: <https://g1.globo.com/politica/noticia/2019/07/10/bolsonaro-diz-que-vai-indicar-ministroterrivelmente-evangelico-para-o-stf.ghtml>. Acesso em: 15 jul. 2021.

IBGE 2010. Censo, amostra religião. Brasília-DF, 2010. Disponível em: <https://cidades.ibge.gov.br/brasil/pesquisa/23/22107>. Acesso em: 12 fev. 2021.

KARNAL, Leandro. Os eleitores de Bolsonaro. Palestra do historiador Leandro Karnal. 2018. Disponível em: 〈https://www.youtube.com/watch?v=cLgQaesNBDU>. Acesso em: 18 fev. 2021.

LEIA JÁ. A vitória de Bolsonaro sem campanha de rua e debates. Recife - PE, Site de notícias e mídia, 2018. Disponível em: <https://www.leiaja.com/politica/2018/10/31/vitoria-debolsonaro-sem-campanha-de-rua-e-debates/>. Acesso em: 22 jan. 2021. 
MENDONÇA, Antonio Gouvêa. O celeste porvir: a inserção do protestantismo no Brasil. $3^{\text {a }}$ ed. São Paulo: EDUSP, 2008.

METRÓPOLES. Brasília-DF, Jornal online, 2020. Disponível em: <https://www.metropoles.com/distrito-federal/politica-df/bolsonaro-participa-de-eventoevangelico-em-estadio-de-brasilia>. Acesso em: 20 mar. 2020.

NETO, Odilon Caldeira. Neointegralismo e as direitas brasileiras: entre aproximações e distanciamentos. Locus - Revista de História, Juiz de Fora, v.18, n.1, p.147-165, 2012.

O GLOBO. Fiéis enfrentam fila em dia de visita de Bolsonaro à igreja no Rio. Rio de Janeiro, 2019. Disponível em: <https://oglobo.globo.com/brasil/fieis-enfrentam-filas-em-dia-de-visitade-bolsonaro-igreja-no-rio-23694744>. Acesso em: 13 fev. 2021.

Três evangélicos disputam vaga aberta no STF em julho. Rio de Janeiro, 2020. Disponível em: <www.oglobo.globo.com>. Acesso em: 10 fev. 2021.

PIERUCCI, Antônio Flávio; MARIANO, Ricardo. O envolvimento dos pentecostais na eleição de Collor. In: Hucitec, 1996. (Orgs.). A realidade social das religiões no Brasil. São Paulo: Editora

PODER360, 2021. Marco Feliciano pressiona Bolsonaro e ameaça entregar vice-liderança do governo. Disponível em: <https://www.poder360.com.br/governo/marco-feliciano-pressionabolsonaro-e-ameaca-entregar-vice-lideranca-do-governo/>. Acesso em: 10 jul. 2021.

PROENÇA, Wander de Lara. Do coreto e a funerária ao templo de Salomão. Portal da Unesp, 12/8/14 Disponível em: <http://www.unesp.br/portal\#!/debate-academico/do-coreto-e-afuneraria-ao-templo-de-salomao/>. Acesso em: 10 jun. 2021.

RÁDIO Jovem Pan REPORTAGEM. Evangélicos e o presidente Jair Bolsonaro, 21 jun. 2019. (13 min.). Disponível em: https://www.youtube.com/watch?v=JGC1QiVY_PU. Acesso em: fev. 2021.

REVISTA Impacto. O ensino das sete montanhas, 2/11/15. Disponível em: www.revistaimpacto.com.br. Acesso em: 21 jan., 2021.

RODA VIVA. TV Cultura, Entrevista com Bolsonaro, 30/07/18. Disponível em: https://www.youtube.com/watch?v=lDL59dkeTi0\&list=LLc2wK142IaZ_Lb_dOVifEwA\&in $\mathrm{dex}=2880$. Acesso em: 18 jan. 2021.

SILVA, Juliano Eugenio da. Pentecostais e neopentecostais na câmara municipal de Curitiba (1989-2016): práticas e representações. 2017. Dissertação (Mestrado em História) Universidade Estadual de Ponta Grossa, Ponta Grossa, 2017.

SURUAGY, Bruna. Afinal, o que os evangélicos querem da política? Revista Exame, Rio de Janeiro, Editora e Comércio Valong, 19 out. 2017. Disponível em: <https://exame.abril.com.br/brasil/afinal-o-que-os-evangelicos-querem-da-politica/>. Acesso em: 10 fev. 2021. 
TEIXEIRA, Francisco Carlos. Programa TV 247, 2018. Disponível em: <https://www.youtube.com/watch?v=jPzdIWZJqrc>. Acesso em: 11 jan. 2020.

THE SEND BRASIL. História. São Paulo, 2020. Disponível em: <http://thesend.org.br/historia-pt/>. Acesso em: 18 jan. 2021.

VALADÃO, Ana Paula (a). Youtube, 2018. Disponível em: <https://www.otvfoco.com.br/anapaula-valadao-apoia-bolsonaro-e-faz-discurso-agressivo-destruir-a-esquerda-podre/ $>$ Acesso em: 10 jan. 2021.

\begin{tabular}{cccc} 
(b). & Youtube, & 2018. & Disponível \\
\hline <https://www.youtube.com/watch?v=mcQC6C6jdJ0>. Acesso em: 22 jan. 2021.
\end{tabular}

VEJA. Os diferentes rostos da direita radical. São Paulo, Editora Abril, 08 abr. 1981.

VEJA Rio. O pastor que se tornou o guru religioso da família Bolsonaro. Rio de Janeiro, 2020. Disponível em: <https://vejario.abril.com.br/cidade/pastor-familia-bolsonaro/>. Acesso em: 20 mar. 2021.

VELOSO, Isabel. Religião e política: como Bolsonaro se tornou o candidato dos evangélicos. Época, Rio de Janeiro, Editora Globo, 8/10/2018. Disponível em: <http://www.ipuemfoco.com.br/2018/10/religiao-X-politica-como-bolsonaro-se.html>. Acesso em: 8 abr. 2021. 